\section{Dr. Silvia Peppoloni}

\section{IUGS Councillor (2018-2022)}

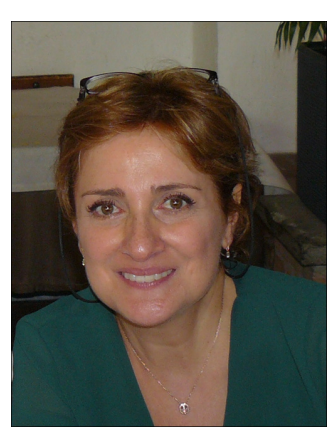

Ever since I was a child, the grandeur of geological phenomena has fascinated me. For hours I used to listen astonished to my grandfather telling me stories about the Vesuvius Volcano: he was from Naples and had personally experienced the destruction of the last eruption in 1944. I remember perfectly the fear and wonder I was feeling while he talked me, the sense of impotence and precariousness that, in my imagination, the population must have felt; that perception of living in a "dancing land", as my grandfather defined Italy. Perceiving that the Earth is a "living" planet and the strength of its processes is that generates similar responses in every living being: that's where my love for geology comes from.

Over time my wish to contribute to the defence of the extraordinary beauty and extreme fragility of my country from natural risks grew so I gradually oriented my career towards the study of georisks and geohazards. In 2002, I participated in the seismic emergency activity in the Molise Region (South Italy). I arrived in the small village of S. Giuliano just a few hours after the earthquake that had destroyed a school, while the firefighters was still trying to extract 27 children buried under the rubble. That's when I realized how much geological knowledge goes beyond the simple intellectual satisfaction and love for science. Geoscientists possess specific knowledge, skills and are prepared for contributing to safe human lives and this entails the ethical duty of using that knowledge to best serve public good.

I'm convinced that geoscientists are key figures to address those current and future global challenges. IUGS is playing a leading role in promoting the increasing involvement of geoscientists in political decisions and can contribute to encouraging the discussion on the ethical and social implications of geological research and practices within the geoscience community.

After graduating in geological sciences, I received a $\mathrm{PhD}$ in Earth Sciences, and since 1999 I'm a researcher at the Italian Institute of Geophysics and Volcanology. My scientific activities and experience cover the fields of geomorphology and engineering geology, focusing particularly on seismic, geomorphological and geotechnical aspects of hazard and risk studies, including their communication to society. Moreover, I'm fully involved in basic research on geoethics, focusing on ethical, social and cultural implications of geoscience knowledge, research and practice, and promoting sustainability, prevention and geo-education as key concepts of the relationship between geoscientists and society.

I have worked as a Professor of geology and applied geology at the University of Rome "Sapienza" and Viterbo "Tuscia" (2008-2011), and in the $\mathrm{PhD}$ course in "Landscape and Environment" at the University of Rome "Sapienza", Faculty of Architecture (2008-2016). Moreover, I have collaborated as researcher with the Polytechnic of Milan (2009-
2011), University of Genoa (2011) and Roma TRE (2005), CNRNational Council of Research (2007-2008).

Since 1999 I have been involved in seismological projects and recently in two European projects dealing with ethical issues. In particular, I'm currently Work Package leader for the ethical and societal issues within the H2020 European Project ENVRI PLUS (20152019) - Environmental Research Infrastructures Providing shared solutions for Science and Society, and I am involved in the European Project Erasmus Plus - GOAL: Geoethics Outcomes and Awareness Learning (2017-2020). As an international proponent of Geoethics, I'm invited to participate as lecturer and chair in various international congresses.

I'm a founding member and current Secretary General of the IAPG - International Association for Promoting Geoethics, Councillor (2018-2022) of the IUGS - International Union of Geological Sciences, member of the Executive Committee of the ICPHS International Council for Philosophy and Human Sciences, member of the Executive Council of the Italian Geological Society, member of the Executive Council of the Italian Section of the IAEG - International Association of Engineering Geology and the Environment.

In 2017 I was selected and included in the Italian online database of the Project "100 Experts - Women against Stereotypes", among the 100 Italian women experts in the fields of Science, Technology, Engineering, Mathematics and Medicine.

I also worked as consultant geologist in the fields of seismic microzonation, subsoil investigations for buildings construction and infrastructures, and risk mitigation of monumental buildings. In 2007 I co-founded the engineering company "IMPACT Group", of which I have been CEO from 2007 to 2011, aiming to integrate multidisciplinary methodologies for the protection of the built and natural environment.

I was teacher in courses on Disaster Risk Reduction (École Polytechnique Fédérale de Lausanne - 2016), seismic damage on cultural heritage (European Project Interreg III C NOÈ - 2007), and seismic vulnerability and fitness for habitation of buildings (FORMEZ Training Center - 2003). In 2016 and 2017 I designed the course "Let's know our territory, let's learn to live with natural hazards" (Italian Project for Secondary Schools: "Alternanza Scuola Lavoro - Italian Law n. 107/2015"). Currently, I'm a Role Model in the Project "Inspiring Girls" (2017-2019), aimed to create consciousness in teenaged girls of their talents.

I have been member of various editorial boards of international journals (among them, the Oxford Handbooks Online "Natural Hazard Science", Oxford University Press).

I'm author of more than 80 scientific articles on international and national journals, editor of books on Geoethics published by Elsevier, Springer, Geological Society of London and Annals of Geophysics, and co-author of the Geoethical Promise (the "Hippocraticlike Oath" for geoscientists), and the Cape Town Statement on Geoethics.

Particularly interested in geoscience communication, I devote myself to the activity of science writer, as contributor of Italian newspapers and magazines, and as author of books on Earth Sciences intended for the general public. With the books "Planet Earth" 
and "Living with natural risks" (both published by Il Mulino, Bologna, respectively in 2014 and 2016) I was finalist of the Italian Science Communication Prize in 2014 and 2016, and awarded with the Italian Prize for Naturalistic Literature in 2017.

I was born and live in Rome (Italy). Keen on music, I studied piano and lyrical singing since I was a child. Among other activities, my past collaboration with the CATTID - Center for Distance Education Techniques of the University Sapienza of Rome, to create tools and supports for use by students with disabilities. 